\title{
Analysis of Coffee Market Chain in Abe Dongoro District of Oromia National Regional State: Ethiopia
}

\author{
Firomsa Mersha Tekalign \\ School of Agricultural Economics and Agribusiness, Haramaya University, Ethiopia
}

\begin{abstract}
This study was aimed at analyzing the determinants of coffee market chain in Abe Dongoro districts of Oromia National Regional State among coffee producers. The data were collected from 160 farmers, 10 traders and 20 consumers and analyzed using descriptive and econometric approaches. The market chain analysis shown that the major actors in the district are coffee producers, collectors, retailers and consumers. It is also found out that coffee passes through several intermediaries with little value being added before reaching the end users. The chain is governed by collectors and retailers who have capital advantage over the other chain actors. Therefore, farmers are forced to capture a lower share of profit margin compared to retailers. The result of the multiple linear regression model indicated that market supply of coffee is significantly affected by access to extension service, amount of coffee produced and marketing price of coffee. Therefore, policy aiming at increasing farmers' access to modern inputs, developing and improving infrastructure and improving extension system are recommended to accelerate the chain's development.
\end{abstract}

Keywords: Coffee; Market Chain; Multiple Regression Model

DOI: $10.7176 / \mathrm{DCS} / 9-12-02$

Publication date: December $31^{\text {st }} 2019$

\section{Introduction}

Coffee accounts for 25 to 30 percent of Ethiopia's total export earnings and about 15 million people are, directly or indirectly, deriving their livelihood from it. It is predominantly produced by small holder farmers on average farms of less than 2 hectares (Tefera and Tefera, 2014).

George et al (2005) pointed out that, most developing countries including Ethiopia have focused for the most part on the issue of changes in the level of average prices faced by producers and consumers of agricultural products under different scenarios. From the perspective of poor countries; there is little evidence that the distribution path has been pursued successfully (Kapanalsky, et al 2001).

Ethiopia possesses coffee types of very high and distinctive inherent qualities that no other coffee producing country can rival. But, these potential qualities are partly lost in the processing and marketing activities. Many agree that Ethiopia could not benefit from its distinctive high quality coffee in the specialty coffee markets due to quality maintenance problems. The other problems are low productivity in coffee production, a weak grading and classification systems, lack of promotion in international markets (Yilma, 1996 cited in Dereje, 2007).

An efficient, integrated, and responsive market mechanism, which is, marketed with good performance, is of crucial importance for optimum allocation of resources in agriculture and for stimulating farmers to increase output (Jones, 1972; FAO, 1999; Acharya and Agarwal, 1999). Without having convenient marketing conditions, the possible increment in output, rural incomes and foreign exchange resulting from the introduction of improved production technologies could not be effective. An improvement in marketing efficiency, thus, attracts the attention of many countries and viewed as an important national development strategy.

Coffee production in Abe Dongoro district is mainly with seasonality where surplus at harvest products is the main characteristics. The lack of organized market system in the study area often resulted in low producers' price. No studies have been carried out to identify what the marketing systems look like and no remedial measures were taken so far. In spite of high potential of Abe Dongoro district for coffee production, producers have not been observed while enjoying returns from production and fare producers share of final consumer prices. This is likely due to the fact that large share of the returns that could have been obtained by coffee production have been lost as result of poor business linkage along market chain actors, post-harvest management, dominance of informal farmer-gate marketing and visual estimation of prices instead of using balance or any scientific measurement for weighing in selling and buying practices of coffee. This, therefore, demanded a holistic study of the system in the form of market chain analysis.

Analysis of coffee market chain in terms of market structure, conduct and performance taking in to consideration the product and location specificity is, therefore, be used to identify the problem and come up with precise possible solution. This study therefore, has attempted to contribute to filling the information gap by investigating the coffee market chain and factors influencing coffee market supply in Abe Dongoro District.

\subsection{Objective of the Study}

The overall objective of the study is to analyze the determinant of coffee market chain in the study area with 
specific objectives:

- To evaluate the marketing costs and benefit shares of actors in coffee market chain in study area.

$\Rightarrow$ To analyze the determinants of coffee market supply in Abe Dongoro district.

\section{Materials and Methods}

\subsection{Description of the Study area}

This study was under taken in Abe Dongoro district of Horo Guduru Wollega zone, Oromia National Regional State, Ethiopia.

Abe Dongoro district is one of the ten districts found in Horo Guduru Wollega zone of Oromia National Regional State, Ethiopia. The district has 22 rural and 2 urban kebeles (i.e. villages). Abe Dongoro district is located about $362 \mathrm{~km}$ north western of Addis Ababa and $47 \mathrm{~km}$ northwestern of Shambu town, the capital of Horo Guduru Wollega Zone of Oromia Region.

The district has total population of about 79,417 of which 34,887 were females. About $25 \%, 60 \%$ and $15 \%$ of the total population are young, economically active and old age, respectively. Average family sizes for the district is 4 persons per household (DOARD, 2015).

Low land (86.33\%) and mid land (10.94\%) agro-ecological zones characterize the district's climate. The district receives mean annual rainfall of $1750 \mathrm{~mm}-2750 \mathrm{~mm}$ and has altitude of 1300 to 2800 above sea level with temperature of $12^{\circ} \mathrm{c}$ to $32^{\circ} \mathrm{c}$. The main rainy season in the district is from April to end of October. The economy of the district is mainly dominated by traditional cash crop farming and major crops produced in the district include coffee, sesame, groundnut, haricot beans and maize (DOARD, 2015).

\subsection{Sampling Design}

The study involved both coffee producers' survey and value chain participants' surveys.

The coffee producers' survey employs two-stage sampling procedure to identify sample respondent household and collect primary data.

At the first stage, one district from Horo Guduru Wollega zone was selected purposively since it represents major coffee production in the Zone.

At the second stage, three potential coffee producing kebeles were purposively selected to represent the district. For the household survey, the sample size of respondents was calculated by using Kothari (2004) formula:

$$
\mathbf{n}=\frac{\mathbf{z}^{2} * \mathbf{p} * \mathbf{q} * \mathbf{N}}{\mathbf{e}^{2}(\mathbf{N}-\mathbf{1})+\mathbf{z}^{2} * \mathbf{p} * \mathbf{q}}
$$

Where, $\mathrm{n}=$ Representative sample respondents

$\mathrm{z}=$ Degree of Confidence level (1.96) at 95\% degree

$\mathrm{p}=$ Proportion of population included in the sample Will be $15 \% \mathbf{( 0 . 1 5 )}$

$\mathrm{q}=$ Proportion of population excluded in the sample

Will be $85 \%(\mathbf{0 . 8 5})$

$\mathrm{e}=$ Standard error (0.05)

$\mathrm{N}=$ total household of sample frame is $\mathbf{7 8 6}$

$\mathrm{n}=\frac{(1.96)^{2} *(0.15) *(0.85) *(786)}{(0.05)^{2}(786-1)+(1.96)^{2} *(0.15) *(0.85)}=\frac{384.98}{2.4} \approx 160$

Sample size of households at kebele level was determined based on probability proportion to size and the households will be identified using simple random sampling technique.

The value chain actor's survey involved identification of 30 individuals composed of input suppliers, traders and consumers.

\subsection{Data Sources and Methods of data collection}

The data were collected from primary and secondary sources. The primary data involved demographic (age, sex, educational level), market (proximity to market, price), institutional (access to credit, extension service, training) and technological (improved seed, agricultural input) characteristics of coffee producers. Data collected from other market actors include type of business (wholesaler, retailer, collector, etc.), buying and selling strategies, initial capital, current working capital, source of working capital, source of market information, demographic characteristics of the traders and other related data were collected. Pretested questionnaires, checklists and trained enumerators were used to collect the primary data. Thus surveys were also supported by key informant interviews and focus group discussions.

The secondary data were collected from district agricultural office annual report, brochure, library, journal, etc. Secondary data were collected on coffee production related characteristics (land, capital and labor).

\subsection{Methods of Data analysis}

The collected data were analyzed by employing both descriptive statistics and econometric model. Descriptive 
statistics were used to analyze the first objective. The econometric model was employed to analyze the second objective. Data analysis was done by SPSS VERSION 20.0 and STATA VERSION 11.0 statistical packages.

\section{Results and Discussion}

\subsection{Descriptive statistics}

\section{Agricultural Services}

In Abe Dongoro district, farmers needed credit to purchase different inputs to enhance the quantity and quality of the coffee production, the short repayment period of the service was suitable to most of the individual respondents. Thus about $75.6 \%$ had access to financial credit during the study period. However, according to the respondents, $46.9 \%$ of them had access to market price information before coffee sold from DAs and kebele administration office.

Trainings and advisory services on agricultural production are provided mainly by the district Agriculture and Rural Development Office and Development Agents. As a result, 96.3\% and 32.5\% of the sample respondents had access to training and extension services to increase the quantity and quality of the commodity at farm level.

\section{Marketing Performance Analysis}

The performance of coffee market was evaluated by considering associated costs, returns and marketing margins. The methods employed for analysis of performance were channel comparison and marketing margin.

The distribution of costs and gross income at different levels is important in the business of coffee. Coffee requires greater attention during harvesting from the point of production to the final market. The marketing cost of the coffee mainly involves the cost of post-harvest activities incurred before reaching the consumer. This includes cost of harvesting and handling (sorting, cleaning, loading, and unloading), and transportation costs. Generally, these components constitute a large share in the total margin between the final retailer price and the cost of production. The margin calculation is done to show the distribution throughout the various actors as coffee move from production to collectors, retail markets, and finally to consumers.

Marketing costs and benefit shares of actors in coffee value chain

Table 1: indicates different types of marketing cost related to the transaction of coffee by chai actors and the benefit share of each chain actors.

\begin{tabular}{|c|c|c|c|c|c|}
\hline Item & & Producer & Collector & Retailer & $\begin{array}{c}\text { Horizontal } \\
\text { Sum }\end{array}$ \\
\hline Purchase Price & & - & 55.33 & 55.35 & 110.10 \\
\hline Production Cost & & 48.76 & - & - & 48.76 \\
\hline \multirow[t]{8}{*}{ Marketing cost } & Labor & 2.50 & 0.50 & 0.37 & 3.37 \\
\hline & Transport & 0.25 & 0.10 & 0.91 & 1.26 \\
\hline & Hulling cost & 0.01 & - & - & 0.01 \\
\hline & Pulping cost & 0.05 & - & - & 0.05 \\
\hline & Packing & 0.01 & 0.01 & 0.15 & 0.17 \\
\hline & material & - & - & 0.32 & 0.32 \\
\hline & Retail shop & & & & \\
\hline & $\begin{array}{l}\text { Tav } \\
\text { Other costs }\end{array}$ & $\begin{array}{l}n 10 \\
0.57\end{array}$ & $\begin{array}{l}025 \\
0.61\end{array}$ & $\begin{array}{l}n 57 \\
0.85\end{array}$ & $\begin{array}{l}n \times 7 \\
2.03\end{array}$ \\
\hline Total Marketing cost & & 3.49 & 1.47 & 3.12 & 8.08 \\
\hline TOTAL COST & & 52.25 & 56.80 & 58.47 & 167.52 \\
\hline Sale Price & & 55.03 & 57.42 & 61.44 & 173.89 \\
\hline Marketing margin & & 3.49 & 1.47 & 3.12 & 8.08 \\
\hline$\%$ Share of margin & & 43.19 & 18.19 & 38.62 & 100 \\
\hline Profit margin & & 2.78 & 0.62 & 2.97 & 6.37 \\
\hline$\%$ Share of profit & & 43.64 & 9.73 & 46.63 & 100 \\
\hline
\end{tabular}

Source: Survey result, 2015

Each of the coffee market chain actors adds value to the product as the product passes from one actor to another. In a way, the actors change the form of the product through improving the grade by cleaning or washing or create space and time utility. That means by simply buying from the farmers and selling to consumers, traders (collectors and retailers) took $56.36 \%$ of the total profit margin. While farmers, doing all the work of producing 
coffee and bearing the associated risks, took $43.64 \%$ of the profit margin. This disproportionate share of benefits is the reflection of power relationship among actors.

\subsection{Econometric Results}

\section{Econometric results of the OLS model}

Estimates of the parameters of the variables expected to determine the market supply of coffee were displayed in Table 2 below. For coffee producers, among a total of 12 explanatory variables included into the econometric model only three variables were found to significantly influence market supply of coffee. These are access to extension services, amount of coffee produced and price of coffee at farm gate.

Table 2: OLS estimation results of determinants of coffee market supply

\begin{tabular}{l|ccc}
\hline Amount of coffee sold(logAMCOSO ) & Coefficients & Robust Std. Err. & $\mathrm{t}$ \\
\hline Age of the respondents(AGE) & 0.004 & 0.004 & 1.01 \\
Sex of the respondents (SEX) & 0.015 & 0.066 & 0.23 \\
Educational level of the house hold(EDUCHH) & 0.013 & 0.024 & 0.54 \\
Family size of the respondents(FASIZE) & 0.005 & 0.009 & 0.56 \\
Farmers years of experience(FARMEX) & -0.004 & 0.005 & -0.80 \\
Access to Extension services(EXSERVI) & $0.131^{* * *}$ & 0.047 & 2.79 \\
Area share of land for coffee(ARSHCO) & -0.001 & 0.007 & -0.14 \\
Amount of coffee produced(AMCOPR) & $0.088^{* * *}$ & 0.008 & 11.00 \\
Access to credit for coffee production(ACCRCO) & -0.067 & 0.049 & -1.37 \\
Off farm income(OFFARM) & -0.006 & 0.052 & -0.12 \\
Distance to nearest market(NEMKTD) & 0.001 & 0.001 & 1.00 \\
Price of coffee at farm gate(PRI_CO) & $0.026^{* *}$ & 0.012 & 2.17 \\
\hline \multicolumn{1}{c|}{ cons } & & & -0.698 \\
\hline
\end{tabular}

Number of obs $=160$

$\mathrm{F}(12,147)=16.47$

Prob $>\mathrm{F}=0.0000$

R-Squared $=0.5223$

Root MSE $=0.29318$

Source: Own computation from survey result, 2015

Note: Dependent variable is amount of coffee sold in $\mathrm{kg}$.

$* * *, * *$ and $*$ are statistically significant at $1 \%, 5 \%$ and $10 \%$, respectively.

Access to Extension services (EXSERVI): Result of the finding indicated that access to extension service was positively and significantly related to the volume of coffee supplied to the market at $1 \%$ significance level. On average, if a coffee producer gets extension contact the amount of coffee supplied to the market increases by 0.131 quintal. This suggests that access to extension service avails information regarding technology which improves production that affects the marketable supply of coffee.

Amount of Coffee Produced (AMCOPR): As hypothesized, the variable was significant at 1\% significant level. A positive coefficient implies that an increase in quantity of coffee produced increases volume of marketable supply of coffee by farmers. It indicates that households who produce more quantity of coffee had also supplied more to the market. The result shows that a one quintal increase in the coffee production causes a 0.088 quintal increase in the volume of marketable supply of coffee.

Market price of coffee (MKTPRI): The coefficient of price of coffee which shows a positive relation to the amount of coffee sold or supplied to market. Producers checked the price of coffee for their best benefit and this directs to the determinant to be the significance at $5 \%$ level. The positive and significant relationship between the variables indicates that as the price of coffee at market rises, the amount of coffee sold at the market also rises, which in turn increases amount of coffee sold per household per year. The coefficient of the variable also confirms that a unit price increase in the coffee market directs to the coffee producing household to raise yearly coffee sales by 0.026 kilograms per quintals.

\section{CONCLUSION AND RECOMMENDATIONS 4.1 Conclusion}

This study was aimed at analyzing the determinants of coffee market chain among coffee producers in the study area. The data were generated from both primary and secondary sources. The primary data were collected from individual interview using pre-tested semi-structured questionnaire and checklist. The primary data for this study were collected from 160 randomly selected households from three kebeles of Abe Dongoro district, 10 traders and 20 consumers. The analysis was made using descriptive statistics and econometric model using SPSS and 
STATA software. Market supply of coffee are found to be important elements in the study of coffee market chain. Therefore, in identifying determinants that affect the market supply of coffee, a multiple regression model was used in the study area.

Coffee market chain analysis of the study areas revealed that the main market chain actors are coffee producing farmers, collectors, retailers and consumers. Collectors were engaged in purchasing coffee from remote areas and sell at markets to retailers and consumers. Retailers purchase coffee from farmers and collectors and sell to consumers. Constraints hindering the development of coffee market chain are found in all the stages of the chain. At the farm-level, coffee producers are faced with lack of modern input supply and high postharvest losses. On marketing side, limited access to market, low price of product, lack of transport, low quality of product and lack of policy framework to control the illegal trade route are the major problems.

Coffee produced in this area passes through several intermediaries, i.e. collectors and retailers, with little value being added before reaching the end-users. The intermediate buyers obtain the coffee from the farmers at a lower price and they sell to the consumers at a higher price. The research result also indicated the absence of organized institution and system group marketing, and lack of processing activities have made traders in a better position to dominate the roost in pricing.

The result of the multiple regression models indicates that market supply of coffee is significantly affected by quantity of coffee produced, access to extension service and market price. Therefore, these variables require special attention if market supply is to be increased.

\subsection{Recommendations}

Contribution of coffee to household's income and nutrition is tremendous. It also provides job opportunities for youth and the landless and for traders and poor urban dwellers engaged in its processing activities. Regardless of its contribution, however, its production and productivity is still low compared to world and regional average. As a result, policy to encourage coffee market chain actors and channels, institutional support provided to the sector such as access to credit, market information and extension services were below the expected level. These factors together with several household personal, demographic and socio-economic factors greatly affected the market supply of coffee and consequently the production and productivity of the sector. Based on the research findings of this study, the following points are recommended to improve marketing supply of coffee so as to enhance its production and productivity.

- The policy of government should appraise coffee market chain actors and channels by encouraging coffee traders.

- Provision of extension service has to be strengthened so as to improve farmers' access to information and extension advices through giving training and other related supports.

- $\quad$ Strengthening and supporting DAs by giving continuous capacity building trainings and separating DAs extension work from other administrative activities increases coffee supply to the market.

\section{REFERENCE}

Abay Akalu, 2007. Vegetable market chain analysis in Amhara National Regional State: the case of Fogera woreda, South Gondar zone. M.Sc thesis presented to the school of graduate studies, Haramaya University. pp70.

Dereje Birhanu, 2007. Assessment of forest coffee value chains in Ethiopia: A case study in Kafa zone, Gimbo district. Agricultural Science and Resource Management in the Tropics and Subtropics (ARTS).German.

FAO (2005).Up grading in the International Tea Sector: A Value Chain Analysis: Committee on commodity problems. Intergovernmental Group on Tea .Bali, Indonesia.

Kaplinsky, R. and M. Morris, 2001. A handbook of value chain analysis. Working paper prepared for the IDRC, Institute for Development Studies, Brighton, UK.

Tefera, A., and T. Tefera. 2014. Ethiopia: Coffee Annual Report, Gain report ET-1402, USDA 